\title{
Ilegalni migranti u tranzitu kao prijetnja sigurnosti građanima Meksika
}

DOI: https://doi.org/10.11567/met.34.3.2

UDK: 314.15:343.343.62]:323(72)

Izvorni znanstveni rad

Primljeno: 12.02.2019.

Prihvaćeno: 22.05.2019.

\section{Lidija Kos-Stanišić}

Fakultet političkih znanosti, Sveučilište u Zagrebu, Zagreb

likos@fpzg.hr

\section{SAŽETAK}

Migracijski val od 2014. do 2016. u kojem je velik broj djece i majki iz država Sjevernog trokuta na putu prema krajnjem odredištu SAD-u bio u tranzitu Meksikom okarakteriziran je krizom. Kriza je podrazumijevala postojanje prijetnje koja opravdava provođenje izvanrednih mjera. Teza rada je da pod utjecajem SAD-a Meksiko migrante u tranzitu smatra prijetnjom sigurnosti građanima Meksika, a ne ugroženim pripadnicima istoga kulturnoga kruga koje treba zaštititi. Stoga se prema njima ne odnosi u skladu s ciljem ljudske sigurnosti, već primjenjuje silu. Rad predstavlja studiju slučaja. U prvom odjeljku dani su prikaz vrsta migracija i poimanje migracija u kontekstu ljudske i građanske sigurnosti, dok su u drugom analizirani potisni i privlačni faktori migracija iz država Sjevernog trokuta. U trećem odjeljku prikazana je politika tranzitne države Meksika prema ilegalnim migrantima. U radu je izložen sud o migracijskoj politici Meksika prema migrantima u tranzitu. Zaključeno je da je iz perspektive ljudske sigurnosti politika bila »loša « jer je bila diskriminirajuća i u neskladu s kulturno-političkim kontekstom te moralnim i zakonskim normama. No gledano iz perspektive nacionalne sigurnosti politika je bila »dobra« jer je bila ostvariva, postigla je rezultate uz prihvatljiv trošak ljudi i sredstva i njome su obranjeni državni interesi Meksika - dobri odnosi sa SAD-om.

KLJUČNE RIJEČI: ilegalni migranti, tranzit, sigurnosna prijetnja, sekuritizacija, Meksiko, Sjeverni trokut

\section{UVOD}

Geopolitički gledano, Latinska Amerika udaljena je od vrućih globalnih sigurnosnih žarišta i ostale svjetske regije znatno su važnije za Latinsku Ameriku nego što je ona važna njima. Iako regija nije sigurnosno zanimljiva svijetu, važna je SAD-u, koji smatra da iz Latinske Amerike dolaze nove 
sigurnosne prijetnje - droga, migracije, uništavanje okoliša, pobunjenici i transnacionalni kriminal (Kacowicz, 2016: 336-342). SAD najviše pozornosti posvećuje bliskom susjedstvu - Meksiku i Srednjoj Americi, kako zbog problema vezanih uz trgovinu drogom tako i zbog ilegalnih migracija. U SAD-u boravi ilegalno oko jedanaest milijuna Latinoamerikanaca. Njihov broj SAD pokušava smanjiti deportiranjem ${ }^{1}$ i onemogućivanjem prelaska granice SAD-a i Meksika. Migracijski smjer Srednja Amerika - Meksiko SAD jedan je od najvećih na svijetu. Prema podacima Ureda Visokog povjerenika Ujedinjenih naroda za izbjeglice (United Nations High Commissioner for Refugees - UNHCR) Meksikom svake godine prođe oko 500.000 migranata. ${ }^{2}$ Migracije iz Srednje Amerike, osobito država Sjevernog trokuta (Gvatemala, Salvador i Honduras) u SAD fenomen je koji traje desetljećima, no u proljeće 2014. započeo je migrantski val koji se od prijašnjih valova razlikovao velikim brojem majki s djecom (family units) i djece bez pratnje odraslih. SAD je vršio pritisak na Meksiko da hitno uvede dodatne mjere protiv migranata koji su s ciljem ilegalnog ulaska u SAD bili u tranzitu Meksikom. Stoga je Meksiko u kolovozu 2014. postrožio migracijsku politiku proglašavajući Programa Frontera Sur (PFS).

Muggah (2017: 395-409) piše da su u Latinskoj Americi legalne i ilegalne migracije povezane, da se preklapaju i da regija posvećuje pozornost upravljanju migracijama, a ne sprečavanju njihovih uzroka. Upravljanje međunarodnim migracijama ključni je izazov država u globaliziranome međunarodnom sigurnosnom okružju. Prvi korak koji suverena država mora poduzeti jest donošenje odgovarajuće migracijske politike, koja će odrediti tko može ući u državu i tko može postati njenim građaninom (Castles, de Haas i Miller, 2014: 198) te tko može biti u tranzitu.

David Haines (2013: 2-4) piše da države oblikuju svoju politiku, tj. plan djelovanja u skladu sa svojim širim vjerovanjima, društvenim uvjetima i etičkim odrednicama. »Dobra« (good) politika trebala bi biti utemeljena na političkom i kulturnom kontekstu države te usklađena s minimalnim međunarodnim normama, za razliku od »loše « (bad) migracijske politike koja je diskriminirajuća i u neskladu s postojećim moralnim i zakonskim normama. U radu će se pokušati odgovoriti na pitanje predstavljaju li srednjoamerički migranti u tranzitu Meksikom sigurnosnu prijetnju. Teza

Od 2009. do 2015. godišnje je deportirano u Meksiko oko 360.000 imigranata. »How a Mexican border is reacting to President Trump«, The Economist, https://www.economist.com/news/ americas/21715827-fear-and-feistiness-how-mexican-border-city-reacting-president-trump.

2 UNHCR FactSheet Mexico,dostupno na http://reporting.unhcr.org/sites/default/files/Mexico $\% 20$ Fact $\% 20$ Sheet $\% 20-\% 20$ Februrary\%202017.pdf. 
rada je da pod utjecajem SAD-a Meksiko transmigrante smatra prijetnjom nacionalnoj sigurnosti Meksika i njenih građana, a ne ugroženim pripadnicima istoga kulturnoga kruga koje treba zaštititi. Stoga je, umjesto da im pomogne, u borbi protiv njih primjenjivao silu. I dok tradicionalne prijetnje ugrožavaju opstanak države, nove prijetnje uz državu ugrožavaju i pojedince. Stoga se, ovisno o prijetnji, primjenjuju »sredstva«. U radu će biti izložen sud je li migracijska politika Meksika prema migrantima u tranzitu tijekom 2014. bila »dobra « ili »loša «.

Prema Lijphartu (1971: 691), ovaj je rad kombinacija ateorijske i interpretativne studije slučaja jer analizira jedan slučaj - migrante u tranzitu Meksikom, deskriptivnog je karaktera, nalazi se $\mathrm{u}$ »teorijskom vakuumu« $\mathrm{i}$ nema namjeru formulirati neku opću teoriju. Prema Thomasu (2011: 515517), ovaj je rad deskriptivna snapshot studija jednog slučaja. ${ }^{3}$ Sastoji se od uvoda, tri odjeljka i zaključka. U prvom odjeljku prikazane su vrste migracija te poimanje migracija u kontekstu ljudske i nacionalne sigurnosti. U drugome su analizirani potisni i privlačni čimbenici migracija iz država Sjevernog trokuta, a u trećemu politika tranzitne države Meksika prema ilegalnim migrantima.

\section{Ilegalne migracije i prijetnje sigurnosti}

Međunarodna organizacija za migracije (International Organization for Migration - IOM) migracije definira kao »Kretanje osobe, ili grupe osoba, kako preko međunarodne granice tako i unutar države. To je kretanje populacije, što uključuje bilo kakvu vrstu kretanja ljudi, nevezano uz njegovu duljinu, sastav i uzroke; uključuje migraciju izbjeglica, prognanih osoba, ekonomske migrante te sve ostale osobe koje se kreću iz drugih razloga, uključujući i spajanje obitelji. « ${ }^{4}$ A: Wertheimer-Baletić (1999) navodi kako se tipologija migracija izvodi ovisno o državnim granicama, trajanju, uzroku, dobrovoljnosti i organiziranosti te ih dijeli na: 1 . vanjske i unutarnje; 2 . stalne $i$ privremene; 3. ekonomske i neekonomske; 4 . dobrovoljne i prisilne; 5 . organizirane i neorganizirane.

Lindey (2014) piše da se u posljednje vrijeme migracije sve češće povezuju

O studiji slučaja vode se brojne metodološke rasprave. Iako postoji više definicija koje studiju slučaja definiraju kao metodu, metodologiju ili dizajn istraživanja, svi se slažu da studija slučaja treba imati jasno vremensko i prostorno ograničenje i dubinski opis jednog ili manjeg broja slučajeva. Isto tako ne postoje ni jedinstvene ili usuglašene tipologije studije slučaja, no mnogi se tipovi studije slučaja kod različitih autora podudaraju.

4 https://www.iom.int/key-migration-terms 
s krizama (crisis migration, migration crisis), a krize kao koncept podrazumijevaju izvanredno stanje i ozbiljnu prijetnju. Time su migracije s margina rasprava o društvenim promjenama došle u središte. Zaključuje kako je prisutna intenzivna politizacija odnosa između kriza i migracija te da politički akteri učestalo interpretiraju »migrantsku problematiku « ovisno o kontekstu koji im odgovara - za skretanje pozornosti s drugih problema ili za potporu nekim političkim mjerama.

Adamson (2006) razlikuje dobrovoljne od prisilnih, ekonomske od političkih (izbjeglice i tražitelji azila), zakonite od nezakonitih i trajne od privremenih migracija te kaže da nije uvijek jednostavno odrediti kojoj kategoriji migranti pripadaju. Browning (2017: 47-51) analizira diskurs američkog predsjednika Donalda Trumpa, koji razlikuje »zakonite« (legal) od »nezakonitih « (illegal) migranata. Pritom ih razlikuje ne samo vezano uz način njihova ulaska u SAD već uvodi i moralnu kategoriju razlikovanja dobrih (good) od loših (bad) ili čak zlih (evil) ljudi. Tako su ilegalni migranti nepoželjni i loši ljudi jer su nezakonito ušli u SAD i jer predstavljaju potencijalnu prijetnju fizičkoj sigurnosti, zdravlju i prosperitetu SAD-a i njegovih građana. Osobito prijete socijetalnoj sigurnosti (societal security), tj. nečemu što zajednica identificira prijetnjom svojem postojanju. Browing podsjeća na rad istaknutog politologa Samuela Huntingtona, koji je u knjizi Tko smo mi još prije četrnaest godina Latinoamerikance okarakterizirao fundamentalnom prijetnjom anglo-protestantskim vrijednostima SAD-a.

Međunarodne migracijeu posljednje vrijemenalaze sena vrhu međunarodne sigurnosne agende, te Adamson (2006: 165) piše kako su stvaratelji politika počeli sve češće povezivati migracijsku politiku i nacionalnu sigurnost. Međunarodne migracije utječu na tri područja nacionalne sigurnosti neke države: na njezin suverenitet, ravnotežu snaga između država i prirodu nasilnih konflikata u međunarodnom sustavu. Pritom je osjećaj da migranti prijete nacionalnom identitetu i kulturnoj koheziji jedan od najvećih izazova suverenim državama. Razvijene države s visokim stupnjem institucionalnih kapaciteta bolje su osposobljene za upravljanje migracijama nego slabe i propadajuće (failing) države. »Sposobnost država da održavaju kontrolu nad vlastitim granicama te oblikuju koherentan nacionalni identitet smatra se nužnim preduvjetom za održavanje državne sigurnosti u drugim područjima « (Adamson, 2006: 176). U posljednje vrijeme učestalo je povezivanje migracija sa sigurnošću, što se čini sekuritizacijom (Castles, de Haas i Miller, 2014: 198). Za međunarodne odnose sekuritizacija ima specifično značenje, a najpoznatija je Waeverova definicija koja sekuritizacijom sma- 
tra proces kojim se »nešto ili netko« predstavlja prijetnjom sigurnosti te se za eliminiranje navedene prijetnje opravdava upotreba izvanrednih mjera. U sekuritizaciju, ali i desekuritizaciju uključeni su vladini zaposlenici, političari, mediji, migranti i njihovi saveznici te javnost. Vrlo je često ključna uloga medija jer način na koji izvještavaju o migrantima (pozitivno ili negativno) vodi ili ne vodi sekuritizaciji (Castles, de Haas i Miller, 2014: 198). Migracije iz siromašnih država često su potaknute nedostatkom ljudske sigurnosti. O problemu nesigurnosti migranata u državama tranzita ili krajnjeg odredišta ne vodi se računa prilikom rasprava o sigurnosti država. Nesigurnost migranata učestalo je uzrokovana osjećajem građana države (tranzita ili krajnjeg odredišta) da ih migranti kulturno (osobito jezično i vjerski), društveno-ekonomski i politički (u smislu da su potencijalno nelojalni i subverzivni) ugrožavaju (Castles, de Haas i Miller, 2014: 199-200).

Koser (2011) piše da proglašavanje migranata prijetnjom sigurnosti ima značajne posljedice po zakone, norme, politike i procedure koji opravdavaju pojačan nadzor, uhićivanja, deportiranje i restriktivne politike. Tražiteljima azila onemogućuje se pristup sigurnim državama te se migranti bacaju u zagrljaj krijumčara ili trgovaca ljudima, pri čemu raste antiimigrantsko raspoloženje. Koser smatra da migracije mogu predstavljati prijetnju nacionalnoj sigurnosti samo u ovim slučajevima: a) kada je migracija neregularna; b) kada je prisutan velik broj migranata; c) kada dolaze u kontakt grupe ljudi vrlo različita porijekla ili grupe koje prije nisu imale značajnije kontakte; d) za razdoblja recesije (i ekonomskih kriza). Za razliku od legalnih migracija, koje su regulirane zakonom, putem kanala koje su države priznale i regulirale, ilegalne migracije povezane su s aktivnostima organiziranih kriminalnih organizacija koje se bave, između ostalog, trgovanjem ljudima i krijumčarenjem ljudi. No pitanje je tko je pritom ugrožen, tj. čija je sigurnost migracijama ugrožena - tranzitne države ili migranata? Fokusirajući se na pojedinca kao referentni objekt sigurnosti, stvorena je nova paradigma ljudske sigurnosti, primarno orijentirana na osobnu sigurnost i slobodu pojedinca kojeg štite država, međunarodne i nevladine organizacije. Tradicionalna nacionalna sigurnost usmjerena je primarno na zaštitu države, koja ima ekskluzivno pravo obrane teritorijalnog integriteta i neovisnosti koju ugrožavaju sukobi, granične razmirice i građanski nemiri, dok se sigurnost postiže primarno silom, ali i ravnotežom snaga $\mathrm{i}$ suradnjom država.

Browning (2017) navodi da migracije predstavljaju vrlo emotivan problem 
koji suprotstavlja prava država pravima pojedinaca te da su sigurnosne implikacije migracija uvijek politički uokvirene i neobjektivne. Navodi primjer američkog predsjednika Trumpa, koji zagovara tradicionalni koncept uloge države i izuzetnu važnost granica za nacionalnu sigurnost te tvrdi da migracije predstavljaju prijetnju nacionalnoj sigurnosti. Nasuprot tome, fotografija mrtvog trogodišnjeg dječaka Aylana objavljena u medijima personalizira tragičnu sudbinu migranata, čime se naglašava humana/humanitarna dimenzija migrantske krize. Usporedba Trumpa i Aylana nameće pitanja čija je sigurnost ugrožena, što sigurnost zahtijeva u različitim kontekstima, što predstavlja prijetnju i kako postići sigurnost - suparništvom ili suradnjom. Kompetitivni pristup pretpostavlja da je sigurnost ograničena i relativna te da se vlastita sigurnost može povećati samo na štetu tuđe sigurnosti (zero-sum). Taj pristup sigurnosti karakterizira tradicionalni (neo) realistički pristup međunarodnim odnosima u kojem sigurnost zahtijeva silu (vojnu i ekonomsku), drugima se pretjerano ne vjeruje i oslanja se na vlastite snage. Zagovara stav da ako ne vode ratu, migracije ne bi ni trebale biti na sigurnosnome dnevnom redu. Naprotiv, kooperativni pristup pretpostavlja da je sigurnost zajednička i da ima neograničene resurse koji se mogu dodatno proširiti prihvaćajući pozitivne odnose povjerenja između pojedinaca i grupa. Taj pristup zagovaraju liberalne i kritičke (konstruktivisti, poststrukturalisti, marksisti i feministi) škole međunarodnih odnosa, koje smatraju da uz političku volju vlastita sigurnost ovisi o sigurnosti drugih (win-win) i stoga znatno više naglašavaju važnost pravde i ljudskih prava (Browning, 2017: 42-46).

Pojedincu i državi prijete tradicionalne i nove prijetnje. U Deklaraciji o sigurnosti Amerika iz 2003. Organizacije američkih država (Organization of American States - OAS) dogovoren je novi multidimenzionalan koncept sigurnosti hemisfere koji uključuje tradicionalne i nove prijetnje i izazove sigurnosti država hemisfere, no migracije se ne spominju. OAS novim prijetnjama identificira: terorizam, transnacionalni kriminal, problem droge, korupcije, pranja novca i trgovine oružjem; ekstremno siromaštvo i socijalnu isključenost većih dijelova društva; prirodne i ljudskom rukom uzrokovane katastrofe, HIV-AIDS, bolesti, prijetnje zdravlju i uništavanje okoliša; trgovanje ljudima; napade na cyber prostor; incidente ili nesreće na moru tijekom transporta potencijalno opasnih materijala; posjedovanje i upotrebu oružja za masovno uništenje povezane s teroristima. Pritom OAS ne zanemaruje tradicionalne prijetnje sigurnosti i njihove mehanizme rješavanja jer smatra da je sigurnost država hemisfere ugrožena kako od 
tradicionalnih tako i od novih prijetnji (Kos-Stanišić, 2010: 56, prema www. osa.org ${ }^{5}$. Kacowicz (2016) pak piše da migracije predstavljaju novu sigurnosnu prijetnju SAD-u. U Latinskoj Americi najviše pozornosti poklanja se »turbulentnoj periferiji« - Meksiku, Srednjoj Americi, Karibima, Kolumbiji i Venezueli (Russell i Calle, 2007).

I Tavares (2014: 1) smatra da ljudska sigurnost ne isključuje tradicionalnu nacionalnu sigurnost jer iako ne dijele cjelokupnu sigurnosnu agendu, vrlo su često komplementarne. Koncept ljudske sigurnosti vuče porijeklo iz 1994., kada je UN izdao Human Development Report u kojem je prvi put pomaknut fokus sigurnosti s države na pojedinca, da bi 2001. bio osnovan Commission on Human Security (CHS). Naime bio je to odgovor na kompleksnost i međupovezanost starih i novih transnacionalnih sigurnosnih prijetnji (siromaštva, etničkog nasilja, trgovanja ljudima, klimatskih promjena, pandemija, terorizma te iznenadnih ekonomskih i financijskih kriza) kao i pokušaj postizanja konsenzusa o isprepletenosti razvoja, ljudskih prava i nacionalne sigurnosti. CHS (2003) navodi da je cilj ljudske sigurnosti zaštita svih ljudskih života na način da se unaprijede ljudske slobode i ispunjenje ljudi, pri čemu ljudska sigurnost podrazumijeva zaštitu temeljnih sloboda onih koje su bit života. Ljudska sigurnost fokusirana je na sigurnost, zaštitu i osnaživanje/davanje moći pojedincu. ${ }^{6}$ Zaštita podrazumijeva top-down pristup, koji priznaje da ljudi ne mogu kontrolirati prijetnje, te je primarno na državama, a u manjoj mjeri međunarodnim i nevladinim organizacijama i privatnom sektoru, da ih zaštiti. To znači da država treba donijeti strategiju zaštite. Davanje moći implicira bottom up pristup, kojim pojedinac razvija otpornost na prijetnje donoseći ispravne odluke kako se s njima nositi, čime sudjeluje u nalaženju rješenja kako postići sigurnost (UNTFHS, 2009: 6-7).

Je li ispravno migracije smatrati prijetnjom sigurnosti, kako nacionalnoj tako i/ili ljudskoj? Prema međunarodnom pravu, države su dužne kontrolirati svoje granice te odlučivati tko može ući, ali i ostati u državi. Wohlfeld (2014: 64-66) piše da je iz perspektive sigurnosnih studija najkorisnije razmatrati status migranata, jesu li »bez papira« (undocumented), nedozvoljeni (unauthorized), tajni (clandestine), ilegalni (ilegal) ili neregularni (irregular).

https://www.oas.org/en/sms/docs/DECLARATION\%20SECURITY\%20AMERICAS\%20 REV\%201\%20-\%2028\%20OCT\%202003\%20CE00339.pdf

6 Ljudska sigurnost interdisciplinarni je koncept kojem je pojedinac u centru analize (people-centered). Razlikuje više vrsta sigurnosti - ekonomsku, prehrambenu, zdravstvenu, okolišnu, osobnu, zajednice i političku (multi-sectoral) te je sveobuhvatnog pristupa (comprehensive). Rješenja problema ovise o kontekstu prijetnje (context-specific) i usmjerena su na prevenciju, zaštitu i davanje moći pojedincu (prevention-oriented) (UNTFHS, 2009: 5-7). 
Termin neregularne migracije upotrebljava IOM i razlikuje ga od ilegalnih migracija, termina koji se upotrebljava u slučajevima krijumčarenja migranata i trgovine ljudima. Neregularnim migracijama IOM smatra pokrete koji se odvijaju izvan regulatornih normi država porijekla, tranzita i krajnjeg odredišta. ${ }^{7} \mathrm{U}$ radu će se za migrante u tranzitu (trans-migrants) Meksikom upotrebljavati naziv ilegalni, a odnosit će se i na neregularne migrante.

\section{POTISNI (PUSH) I PRIVLAČNI (PULL) ČIMBENICI MIGRIRANJA IZ DRŽAVA SJEVERNOG TROKUTA}

Migracije potiču potisni i privlačni čimbenici. Dok prvi potiču ljude na migriranje iz domovine, drugi ih privlače u zemlju krajnjeg odredišta. ${ }^{8}$ Želju za životom u SAD-u jednostavno je objasniti sintagmom »američki san«, dok su potisni čimbenici znatno brojniji i kompliciraniji. Najčešće se dijele na prirodne, ekonomske, kulturne i društveno-političke, a gotovo su svi navedeni faktori prisutni u državama Sjevernog trokuta. Gvatemala, Honduras i Salvador nove su demokracije koje se suočavaju s tipičnim tranzicijskim, sistemskim i kontekstualnim problemima Latinske Amerike (Kos-Stanišić, 2013). Već je nekoliko godina Sjeverni trokut najnasilnija svjetska regija koja se nalazi izvan aktivnih ratnih zona. Većinu nasilja provode transnacionalne kriminalne organizacije koje se bave trgovinom drogom (Drug Trafficking Organizations - DTO), meksički narkokarteli i bande mare. Početni razlog nasilja u državama Sjevernog trokuta bile su deportacije pripadnika mara iz SAD-a, koji su se zatim asimilirali s domaćim bandama (pandillas). Mare su nastale tijekom osamdesetih godina 20. stoljeća kada je tijekom srednjoameričkoga konflikta ${ }^{9}$ oko milijun stanovnika Salvadora i Gvatemale emigriralo u SAD. Tamo su osnivali prve bande, kojima su se poslije priključili i srednjoamerički susjedi. Ističu se Mara Salvatrucha (MS-13) i Barrio 18 (M-18), koje Kacowicz (2016) smatra ozbiljnom prijetnjom sigurnosti hemisfere. Članovi mara su mladi u dobi od 8 do 35 godina koji su prigrlili kriminalni životni stil i identitet. SAD je devedesetih započeo s politikom

\footnotetext{
https://www.iom.int/key-migration-terms

https://www.iom.int

9 Godine 1979. na vlast u Nikaragvi došla je ljevičarska Sandinistička fronta. U namjeri da poraze sandiniste i spriječe da se revolucija i dolazak ljevičara na vlast preliju na susjedne države, SAD je u skladu sa svojom hladnoratovskom politikom surađivao s desnim vladama Sjevernog trokuta i obilato ih nagrađivao vojnom pomoći. U Hondurasu su se nalazile baze nikaragvanskih kontrarevolucionara koje je financirao SAD, dok su Salvador i Gvatemala američku pomoć i potporu upotrebljavali u borbi protiv domaćih revolucionara. Tijekom sukoba koji je završio potpisivanjem sporazuma 1987. milijun stanovnika imigriralo je u SAD (Kos-Stanišić, 2013 :86).
} 
deportiranja nelegalnih imigranata matičnim državama. Među njima je bio značajan broj marerosa s kriminalnim dosjeima. Tako je sredinom devedesetih u samo tri godine deportirano 150.000, a od 1998. do 2005. još 46.000 pripadnika mara. Aktivnostima mara u državama Sjevernog trokuta osobito su ugroženi siromašni građani koji nemaju sredstava da angažiraju privatne zaštitare kao što to čine bogati, već trpe nasilje i zastrašivanje. Marama je najunosniji posao reketarenje tj. iznuđivanje "zaštite« sitnim poduzetnicima (Kos-Stanišić, 2012: 34-37). Pretpostavlja se da je 2012. bilo oko 54.000 pripadnika mara u državama Sjevernog trokuta - 12.000 u Hondurasu, 20.000 u Salvadoru i 22.000 u Gvatemali. Salvador je imao najveći broj marerosa po glavi stanovnika - 323 na 100.000 (Ribando Seelke, 2013: 3).

Zatvaranjem karipskoga koridora i agresivnim aktivnostima meksičke vlade protiv DTO-a, Srednja Amerika postala je glavni tranzitni smjer krijumčara droga, većinom kokaina, iz Južne Amerike u SAD. Narkokarteli i mare već su nekoliko godina u državama Sjevernog trokuta ključni kršitelji ljudskih prava. Oduzimaju građanima pravo na život i sigurnost te jednakost pred sudovima i potkopavaju rad vladinih institucija zaduženih za istrage i kažnjavanje (Kos-Stanišić, 2013). Građane reketare i ucjenjuju, ${ }^{10}$ a kad novac ne dobiju, ubijaju. Prisiljavanje djece i mladih da postanu članovi bandi, ili će biti zlostavljani ili ubijeni, jedan je od glavnih razloga migriranja nakon 2013. (Portillo Villeda i Miklos, 2017: 57). Ujedno, u državama Sjevernog trokuta učestalo je obiteljsko i seksualno nasilje, a po ubojstvima žena (femicid) regija je na vrhu svjetske ljestvice. Po broju ubojstava žena u od 2004. do 2009. Salvador je bio na prvome mjestu (12 ubijenih žena na 100.000), Gvatemala na trećemu (9,7 ubijenih žena na 100.000), a Honduras na sedmome. ${ }^{11}$ Najelementarnije ljudsko i građansko pravo, pravo na život, u Hondurasu, Salvadoru i Gvatemali ozbiljno je ugroženo.

Ujedno, Srednja Amerika prirodnim je nepogodama među najugroženijim regijama svijeta kojom učestalo haraju uragani, poplave, klizanje terena, potresi i vulkanske erupcije. Posljednjih nekoliko godina pridružila im se i suša, koja izaziva nestašicu hrane. Prema podacima WFP-a (World Food Program) i IOM-a 3,5 milijuna građana Srednje Amerike nema dovoljno hrane (food insecure), što je dodatni poticaj za migriranje dijela propalih sitnih poljoprivrednika (Chishti i Hipsman, 2016: 3). Pristup primarnoj

10 Pretpostavlja se da se godišnje na plaćanje ucjena troši u Salvadoru 390 milijuna USD, u Hondurasu 200 milijuna USD, a u Gvatemali 61 milijun USD (WOLA, 2016: 4).

${ }_{11}$ http://www.smallarmssurvey.org/fileadmin/img/highlights/Femicide-RN14-fig2.pdf 
zdravstvenoj zaštiti, osobito u ruralnim područjima, stanovnicima država Sjevernog trokuta vrlo je ograničen. U Salvadoru na 1000 stanovnika ima 1,6 liječnika opće prakse, u Gvatemali 0,93, a u Hondurasu tek 0,37, što je nedovoljno za adekvatnu zdravstvenu skrb. ${ }^{12}$

R. Muggah (2017: 397) smatra da je glavni razlog mješovitog migriranja ${ }^{13}$ u Latinskoj Americi u 21. stoljeću osjećaj nesigurnosti. U slučaju država Srednje Amerike prisutno je masivno raseljavanje unutar i izvan granica država, uzrokovano strahom od kriminalnog nasilja (bandi maras i pandilla te narkokartela), dok je tijekom sedamdesetih i osamdesetih godina 20. stoljeća uzrok bio oružani sukob koji je vladao podregijom.

Nakon opisa situacije u državama Sjevernog trokuta može se zaključiti kako su u Gvatemali, Hondurasu i Salvadoru prisutne brojne prijetnje ljudskoj sigurnosti koje građane tjeraju iz zemlje: 1. osobna nesigurnost - obiteljsko nasilje, kriminal; 2. politička nesigurnost - kršenja ljudskih prava; 3. ekonomska nesigurnost - kronično siromaštvo i nezaposlenost; 4 . okolišna nesigurnost - učestale prirodne nepogode; 5 . nesigurnost zajednice - prijetnje mara; 6. nesigurnost hrane - učestali nedostatak hrane; 7. zdravstvena nesigurnost - neishranjenost i nemogućnost korištenja osnovnom zdravstvenom zaštitom (Kos-Stanišić, Čančar i Richardson, 2018: 466). Da je strah jedan od glavnih uzroka migriranja, pokazalo je i istraživanje Sveučilišta Vanderbilt, koje je ustanovilo da građani koji su bili žrtve kriminala znatno češće namjeravaju migrirati, osobito u Salvadoru i Hondurasu (Hiskey, Cordova, Orces i Malone, 2016).

Tablica 1. Vrste ljudske sigurnosti i glavne prijetnje u državama Sjevernog trokuta

Table 1. Types of human security and main threats in the states of Northern Triangle

\begin{tabular}{|l|l|}
\hline Vrsta sigurnosti & primjeri glavnih prijetnji \\
\hline Osobna sigurnost & kriminal, obiteljsko nasilje \\
\hline
\end{tabular}

12 https://www.cdc.gov/immigrantrefugeehealth/profiles/central-american/healthcare-diet/index.html

13 Muggah (2017: 395-409) piše da su u Latinskoj Americi legalne i ilegalne migracije povezane i da se preklapaju, zbog čega za prije navedenu vrstu isprepletenih migracija upotrebljava termin »miješane migracije«. Pritom razlikuje: 1 . dobrovoljno ekonomsko migriranje; 2. razvojem inducirano raseljavanje; 3 prirodnom nepogodom inducirano raseljavanje; 4 . nasiljem inducirano raseljavanje (izbjeglice i interno raseljeni); 5.osobe bez državljanstva. 


\begin{tabular}{|l|l|}
\hline Politička sigurnost & kršenje ljudskih prava \\
\hline Ekonomska sigurnost & kronično siromaštvo i nezaposlenost \\
\hline Okolišna sigurnost & prirodne katastrofe \\
\hline Sigurnost zajednice & $\begin{array}{l}\text { međuetničke i druge napetosti utemeljene na identitetu } \\
\text { (mare) }\end{array}$ \\
\hline Prehrambena sigurnost & nedostatak hrane \\
\hline Zdravstvena sigurnost & $\begin{array}{l}\text { pothranjenost i } \\
\text { nedostatak pristupa osnovnoj zdravstvenoj zaštiti }\end{array}$ \\
\hline
\end{tabular}

Izvor: United Nations Trust Fund for Human Security - UNTFHS (2009). Human Security in Theory and Practice. New York, str. 6.

\section{POLITIKA MEKSIKA PREMA MIGRANTIMA U TRANZITU NAKON 2001.}

Lopez (2015) identificira pet razdoblja imigracijske povijesti Meksika. Prvo je bilo razdoblje imigriranja niskog intenziteta (1821. - 1876.), drugo sponzoriranog dolaska europskih imigranata (1876. - 1910.), treće zatvaranja granica (1910. - 1973.), osim u slučaju primanja dvadesetak tisuća obrazovanih i dobrostojećih španjolskih republikanaca 1937. - 1938., a u četvrtom razdoblju provodila se uglavnom politika laissez-faire s povremenim angažmanom (1973. - 2000.), koje je u novom tisućljeću vodilo angažiranju vezanom uz problematiku migranata $u$ tranzitu.

Ovisno o smjeru kretanja migranti u tranzitu od južne do sjeverne granice Meksika moraju prijeći između 2000 i 3500 kilometara. Zatim ih čeka 3200 kilometara duga granica sa SAD-om. Problemi Meksika s migrantima iz Srednje Amerike započeli su osamdesetih godina 20. stoljeća. Za srednjoameričkoga konflikta više od milijun stanovnika regije emigriralo je u SAD. Nakon što su se smjestili u SAD, poticali su članove obitelji da im se pridruže, te je SAD zatražio od Meksika da efikasnije kontrolira svoju južnu granicu. Nakon američkih kritika broj deportacija iz Meksika od 1988. do 1990. značajno se povećao. SAD je tijekom devedesetih sve više učvršćivao svoju južnu granicu. Vrhunac je bio nakon 11. rujna 2001., kada je SAD sekuritizirao svoje odnose s Latinskom Amerikom (Domínquez, 2010: 13-14). Osobito se to odnosilo na Meksiko, kojem je u strahu da teroristi ne bi preko meksičkog teritorija ušli u SAD i počinili novi teroristički napad posvećena posebna pozornost u sklopu »globalnog rata protiv terora «. Meksiko je za vladavine predsjednika Vincenta Foxa (2000 - 2006.) svoju 
solidarnost sa SAD-om demonstrirao proglašavanjem Plana Jug (Plan Sur) i pojačanom deportacijom migranata, među kojima nije bilo terorista. Ipak, Meksiko je dao do znanja da se slaže sa SAD-om da su migracije prijetnja nacionalnoj sigurnosti 2005., kada je Nacionalni institut za migracije (INM) uključio u sastav Vijeća za nacionalnu sigurnost (Isacson, Meyer i Morales, 2014: 20).

Podaci Ministarstva unutarnjih poslova Meksika (SEGOB) pokazuju da je broj ilegalnih migranata iz Srednje Amerike, većinom iz država Sjevernog trokuta, koji su nelegalno bili u tranzitu Meksikom 2000. bio oko 236.000, 2005. oko 433.000, a 2010. oko 140.000. Više od polovine navedenog broja migranata deportirano je iz Meksika.

Predsjednik Felipe Calderón (2006. - 2012.) nastavio je politiku svog prethodnika i proglasio Programa Frontera Sur Segura, za koji se navodilo da su mu ciljevi zaštita ljudskih prava migranata, moderniziranje graničnih prijelaza i identificiranje osoba koje prelaze granicu. Time je program bio prethodnica PFS-u. Sigurnost državnih granica vezana je uz nacionalnu sigurnost, zbog čega je Meksiko pojačao prisutnost snaga reda na jugu države i militarizirao ga.

I ne samo to; Meksiko je za ulazak u zemlju stavio uvjet posjedovanja viza za građane 135 država. Znakovito je da se među njima nalaze države koje sa SAD-om imaju komplicirane odnose - Afganistan, Sjeverna Koreja, Kuba, Iran, Irak te veći broj bliskoistočnih i srednjoazijskih država. Razlog je bio uvjeriti SAD da Meksiko čini sve kako »potencijalni teroristi« ne bi mogli legalno ući u Meksiko i rutama kojima se koriste migranti ilegalno prijeći u SAD. Pritom je značajno spomenuti da je Meksiko ispred svog turizma i rasta GDP-a stavio sigurnost hemisfere, tj. SAD-a (Noricumbo Robles, 2017).

Meksiko se našao u »nezgodnoj situaciji« jer su susjedne južne države tražile zaštitu svojih građana u tranzitu, a susjedi sa sjevera onemogućivanje tranzita - ne samo migranata već i droge za američko tržište. Dolaskom na vlast meksički predsjednik Calderón morao se suočiti s problemom narkokartela, koji su onemogućivali funkcioniranje države na dijelu teritorija. Proglasio im je rat i na ulice poslao 50.000 vojnika, što je vodilo militarizaciji javne sigurnosti. Borbu protiv narkokartela i oslanjanje na vojsku nastavio je i predsjednik Enrique Peña Nieto (2012. - 2018.). Vladine akcije remete ravnotežu snaga među kartelima, pa između njih dolazi do sve većeg nasilja i borbi za moć i teritorije. ${ }^{14}$ Kriminalne organizacije ne bave se samo trgovinom dro-

14 Godine 2017. bili su aktivni »stari« karteli - Los Zetas, Zaljevski, Sinaloa, Juarez i Tijuana, dok 
gom već i krijumčarenjima, trgovanjem ljudima, reketarenjem i u posljednje vrijeme krađom nafte iz naftovodâ. Da je sigurnosna situacija u Meksiku vrlo komplicirana, pokazuje podatak da je od 2006. do 2016. godine 109.000 građana ubijeno, a 30.000 ih je nestalo (Selke Finkea, 2017).

Meksiko je nakon 2001. počeo voditi restriktivnu migracijsku politiku. Vrhunac je bio 7. srpnja 2014., kada je predsjednik Peña Nieto proglasio novu strategiju meksičke južne granice - Programa Frontera Sur. Definicijom »južna granica« obuhvaćene su savezne države koje dijele gotovo 750 milja $(1138 \mathrm{~km})$ porozne granice s Gvatemalom i Belizeom. Prema Wilson i Valenzuela (2014: 1-2), glavni deklarirani ciljevi PFS-a bili su zaštita migranata u Meksiku i upravljanje graničnim prijelazima na način da se osiguraju sigurnost i blagostanje regije. Kontroliranje južne granice pomaknuto je sto milja u unutrašnjost zemlje (Isacson, Meyer i Morales, 2014).

Tranzit migranata kroz Meksiko nikad nije bio jednostavan ni siguran, no donošenjem strategije Programa Frontera Sur postao je znatno teži i nesigurniji, te su ga učestalo kritizirale udruge civilnog društva koje se bave zaštitom ljudskih prava i migranata, ali i međunarodne organizacije kao što je UNHCR.

Na terenu je PFS vodio aktiviranju dodatnog broja agenata Nacionalnog instituta za migracije (INM), koji su se, doduše bez oružja, priključili federalnoj, saveznoj i municipalnoj policiji u kontroli migranata. Povećan je broj racija i provjera, a agenti u civilu lovili su migrante koji su putovali najčešćim tranzitnim prijevoznim sredstvom, vlakom La Bestia, koji tračnicama spaja jug sa sjeverom Meksika (WOLA, 2016: 14). Ujedno je INM imao plan da će zahvaljujući stotinu mobilnih kontrolnih točaka na autocestama, stvarati bazu biometrijskih podataka migranata. No povećani priljev migranata iz Kube, Afrike i Azije osujetio im je planove (Clare Seelke, 2015: 1). Budući da su uhodani tranzitni smjerovi bili pod nadzorom, migranti su bili prisiljeni raspršiti se i služiti se skrivenijim i opasnijim smjerovima. Promjenom načina i smjera kretanja postali su manje uočljivi te time i izloženiji nevoljama. Osim što su ih meksički organi reda mogli uhititi i deportirati, bili su izloženi stradavanjima te učestalim kriminalnim radnjama i kršenjima ljudskih prava, kao što su otmice i traženje otkupnina, seksualno zlostavljanje ili pretvaranje u seksualno roblje te pljačke i ubojstva. Ujedno, postali su dodatan izvor zarade ne samo pripadnicima narkomiljea i

su se od novih kartela isticali Los Caballeros Templarios Guardia Michoacana, nastali nakon raspada kartela La Familia Michoacana, i CJNG (Cartel de Jalisco Nueva Generacion); www. insightcrime.org 
krijumčarima ljudi već i snagama reda. Castillo (2016: 2) zaključuje da je nakon dvije godine provođenja Programa Frontera Sur evidentno da je Meksiko dao primat zatvaranju i deportaciji migranata, a ne njihovoj zaštiti. Prema podacima SEGOB-a, nakon donošenja Programa Frontera Sur broj deportacija značajno je porastao. Meksiko je 2013. deportirao 80.079 migranata, uglavnom iz Srednje Amerike. Od navedenog broja 8350 bila su djeca. Godine 2014. broj deportiranih iznosio je 107.814, od čega 18.169 djece (Boggs, 2015). UNHCR je upozorio da bi polovina djece bez pratnje i značajan broj žena trebali dobiti međunarodnu zaštitu i da bi ih trebalo smatrati izbjeglicama. Unatoč tome broj odobrenih zahtjeva za azil je nizak. Migranti nisu upoznati sa svojim pravima, a i nakon uhićenja migracijski agenti rijetko ih upoznaju s mogućnošću traženja azila. Ipak, broj zahtjeva se iz godine u godinu povećava, no COMAR (Comision Mexicana de Ayadu de Refugiados) nema dovoljno službenika ni smještajnih kapaciteta za tražitelje azila, zbog čega procedura traje vrlo dugo.

Castillo (2016: 3-4) piše da je 2013. Meksiko zaprimio 1296 zahtjeva za azil, a odobrio 280; godine 2014. od 2137 zahtjeva odobreno je 456, a 2015. od 3424 zahtjeva 949 . Zahtjevi za vize porasli su u tri godine za $169 \%$, a pritom COMAR-u nisu povećana sredstva (dva milijuna USD), za razliku od INMa, koji za zatvaranje i deportaciju migranata, između ostalog, raspolaže s 86 milijuna USD. U prvih devet mjeseci 2016. azil su u Meksiku zatražila 5944 migranta; odobreno ih je 1746, a 326 migranata dobilo je zaštitu (WOLA, 2016: 15).

Migrantima u tranzitu najviše pomažu vjerske humanitarne nevladine organizacije. Krajem 2016. u Meksiku je zabilježeno 85 takvih organizacija koje su migrantima osim hrane, prve pomoći i prenoćišta nudile i savjete o zaštiti njihovih ljudskih prava (Olayo-Mendez, 2017: 10).

Arriola Vega (2016: 3) piše da je jedna od kritika PFS-a vezana uz financiranje koje dolazi iz Merida inicijative, čiji je primarni cilj borba protiv trgovine drogom i kriminala, a ne rješavanje problema granica i migranata. Iako OAS ima Odbor za multidimenzionalnu sigurnost, migrantska problematika nije u nadležnosti OAS-a, već država izravno uključenih u »migrantsku krizu«SAD-a, Meksika i država Srednje Amerike.

Godine 2007. predsjednici G. W. Bush i F. Calderon sastali su se u Meridi i dogovorili američku pomoć Meksiku u borbi protiv droge i kriminala. Za predsjednika Obame 2011. provedena je revizija strategije, te je fokus $\mathrm{s}$ transfera tehnologije (zrakoplovi i helikopteri) prebačen na izgradnju 
institucija (institution building), ekonomski razvoj i socijalne programe uz granicu Meksika sa SAD-om. Glavne zadaće Merida inicijative počivale su na četiri stupa: 1 . sprečavanje aktivnosti kriminalnih organizacija; 2 institucionaliziranje vladavine prava i zaštite ljudskih prava; 3. stvaranje moderne/suvremene granice (za 21. stoljeće); 4 . stvaranje jakih i otpornih zajednica. U prvoj fazi Merida inicijative najviše se novaca trošilo na prvi stup, a od 2011. na drugi stup. Inicijativi su pridružene i države Srednje Amerike. Budući da su se borbe protiv narkotrafikanata i migranata počele sve više preklapati, dogovoreno je da se fokus prebaci na američku pomoć u konsolidiranju porozne i nesigurne južne meksičke granice. Stoga je od 2013. meksička vlada provodila plan dodatnog osiguravanja južne granice koji je predviđao stvaranje dvanaest riječnih kontrolnih baza i tri sigurnosna pojasa kontrole sto milja sjeverno od granice s Gvatemalom i Belizeom. SAD je uložio 24 milijuna USD za neinvazivnu inspekcijsku opremu i obuku migracijskih agenata te vojske. Ujedno, povećana su sredstva za UNHCR kako bi razvio program obuke migracijskih agenata za intervjuiranje ranjive populacije i vođenje humane repatrijacije. SAD je za Merida inicijativu od 2008. do 2016. izdvojio 2,8 milijardi USD, od čega je Meksiko dobio 1,6 milijardi. Time su se, prema viđenju SAD-a, meksička sigurnost i vladavina prava značajno povećale. State Department Inicijativu ocjenjuje uspješnom, a kao jedan od pokazatelja uspješnosti navodi činjenicu da je Meksiko 2015. i 2016. uhitio 150.000 migranata iz Srednje Amerike (Ribando Seelke i Finklea, 2017: 1-25).

Migrantska kriza imala je značajne posljedice na odnos Meksika i SAD-a, ali i Meksika i država Srednje Amerike. U očima SAD-a i stvaratelja američke vanjske politike poraslo je značenje Meksika kao regionalnog partnera koji zaustavlja dolazak ilegalnih migranata (ali i potencijalnih terorista) u SAD, osobito u sklopu Merida inicijative. $S$ druge strane, stanovnici Srednje Amerike zamjerili su Meksiku politiku produžene ruke SAD-a koja provodi neprijateljsku politiku prema susjedima, dok su vlade država regije upotrebljavale diplomatski rječnik (Donnelly, 2014: 11-12).

\section{ZAKLJUČAK}

Migracijski val od 2014. do 2016. u kojem je veliki broj djece i majki iz država Sjevernog trokuta na putu prema SAD-u bio u tranzitu Meksikom okarakteriziran je krizom. Kriza je podrazumijevala postojanje prijetnje koja opravdava provođenje izvanrednih mjera. Suočavanje s problema- 
tikom migranata u tranzitu Meksikom nije bila novost. Još od kraja osamdesetih godina 20. stoljeća pod pritiskom SAD-a Meksiko je deportirao migrante u tranzitu u zemlje porijekla. Kako se Meksiko sve više povezivao sa SAD-om, rasli su i potreba značajnijeg udovoljavanja »američkim zahtjevima « i razumijevanje »američkog straha od nelegalnih migranata. Strah je nakon 11. rujna 2001. prerastao gotovo u paranoju. Vlade meksičkih predsjednika Foxa, Calderona i Niete donosile su i provodile restriktivnu migracijsku politiku sukladno američkoj politici/stavu da migranti predstavljaju prijetnju nacionalnoj sigurnosti i građanima Meksika, čime je teza rada potvrđena. Iako je opetovano naglašavao namjeru zaštite migranata u tranzitu, Meksiko je militarizirao i sekuritizirao svoju migracijsku politiku. Bilo je to osobito vidljivo nakon proglašenja Programa Frontera Sur 2014., koji je iste metode - uhićivanje, deportaciju i uskraćivanje prava na azil primjenjivao na ranjivoj populaciji žena i djece, koji su većinom zadovoljavali kriterije za priznavanje statusa izbjeglice. PFS je isticao namjeru zaštite migranata, efikasnijeg upravljanja graničnim prijelazima te stvaranja zona sigurnosti i blagostanja na jugu države. No nakon dvije godine provođenja programa moglo se zaključiti da namjera, osobito zaštite migranata, nije ostvarena. Dapače, migranti u tranzitu dodatno su izloženi nevoljama i stradanjima te kršenju svojih osnovnih ljudskih prava, kako od kriminalnih organizacija tako i snaga reda. Time je njihov tranzit postao znatno nesigurniji nego što je bio. Ujedno, ljudska prava krši im i država Meksiko, koja im uskraćuje pravo na azil ili priznavanje humanitarnih viza. Prema migrantima Meksiko se nije odnosio u skladu s ciljem ljudske sigurnosti, već je primjenjivao silu. Tome u prilog ide i činjenica da je COMAR za pomoć izbjeglicama godišnje raspolagao s dva milijuna USD, a INM za zatvaranje i deportaciju migranata s 86 milijuna USD. Ni granica na jugu države nije postala sigurnija. Da je PFS u skladu s američkim interesima, vidljivo je iz činjenice da je njegov glavni financijer SAD, koji je preko Merida inicijative uspio povezati borbu protiv droge i migranata u tranzitu.

Pitanje je zašto su migranti unatoč svemu navedenome nastavili pristizati? Bila je to nada da će se ipak nekako dokopati SAD-a ili, u najgorem slučaju, ostati u Meksiku. Naime najelementarnije ljudsko pravo jest pravo na život, a ono je u državama Sjevernog trokuta ugroženo. Uz osobnu nesigurnost, u Gvatemali, Hondurasu i Salvadoru prisutne su i druge prijetnje ljudskoj sigurnosti koje građane primoravaju na bijeg i emigriranje - politička, ekonomska, okolišna te zdravstvena i prehrambena nesigurnost.

Trebali li srednjoameričke migrante u tranzitu Meksikom smatrati sigurnos- 
nom prijetnjom građanima Meksika? Odgovor je: ne. Meksiko, Gvatemala, Honduras i Salvador pripadaju istome kulturnom krugu. Osim što vrlo slično izgledaju, dijele povijest, katoličanstvo i španjolski jezik, te kulturno, a ni politički ne mogu ugroziti građane Meksika. Vjerojatno dio građana, osobito na tranzitnoj ruti, osjeća društveno-ekonomsku prijetnju smatrajući da su migranti teret jer se na njih troše značajna financijska sredstva koja bi se mogla potrošiti na dobrobit građana Meksika. Važno je spomenuti i meksički paradoks, jer već neko vrijeme simultano zagovara i provodi antiimigracijsku i proemigracijsku politiku, što prema Kimballu (2007: 140) dugoročno neće biti moguće.

Nakon svega navedenoga teško je dati sud o meksičkoj migracijskoj politici. Gledamo li iz perspektive ljudske sigurnosti, politika je »loša « jer je diskriminirajuća i u neskladu s kulturno-političkim kontekstom, kao i moralnim i zakonskim normama. Promijenimo li perspektivu i gledamo iz kuta nacionalne sigurnosti, politika je »dobra« jer je ostvariva, postigla je rezultate uz prihvatljiv trošak ljudi i sredstava i njome su obranjeni državni interesi Meksika - dobri odnosi sa SAD-om. Ujedno, migracijska politika jedan je od alata kojim se u budućnosti Meksiko može koristiti ako američki predsjednik Trump donese odluke protivne meksičkim interesima, kao što su značajno oporezivanje meksičkih proizvoda i deportiranje velikog broja Meksikanaca koji ilegalno borave u SAD-u.

Problem migrantskog vala majki i djece iz država Sjevernog trokuta koji su od 2014. do 2016. bili u tranzitu Meksikom pokušavao je riješiti silom, a ne brigom o sigurnosti pripadnika istoga kulturnoga kruga. Castles, de Haas i Miller (2014: 5) pišu da je u slučaju Meksika prisutna proliferacija tranzicije migracija (migration transition), jer od države emigranata postaje državom imigranata. Naime dolaskom Trumpa na vlast Meksiko je sve više ne samo tranzitna zemlja već i zemlja krajnjeg odredišta. Trumpova imigracijska politika prema imigrantima iz Srednje Amerike pati od duboke povijesne amnezije vezane uz ulogu SAD-a u srednjoameričkom konfliktu osamdesetih godina 20. stoljeća koji je značajno destabilizirao regiju. Štoviše, Trump obitelji, žene i djecu koji su pobjegli od nasilja čijem je stvaranju i SAD pridonio proglašava opasnim kriminalcima i demonizira ih (Portillo Villeda i Miklos, 2017: 53-54). To je jedan od razloga što je Trumpovim dolaskom na vlast broj uhićenih migranata iz Srednje Amerike na južnoj granici SAD-a značajno smanjen, dok je znatno porastao broj tražitelja azila u Meksiku. U prosincu 2018. u Meksiku je došlo do promjene vlasti. Pitanje je hoće li novi, izrazito lijevo orijentirani predsjednik Andrés Manuel López Obrador 
promijeniti politiku i hoće li migrante iz država Sjevernog trokuta smatrati prijetnjom nacionalnoj sigurnosti Meksika ili susjedima i braćom koje treba zaštititi.

\section{LITERATURA}

Adamson, F. (2006). Crossing Borders: International Migration and National Security, International Security, 31 (1): 165-199, doi:10.1162/isec.2006.31.1.165

Arriola Vega, L. A. (2016). Mexico's Not-So-Comprehensive Southern Border Plan. Houston: Rice University's Baker Institute for Public Policy (Issue Brief, 08.05.16). https:// www.bakerinstitute.org/media/files/files/329273a1/BI-Brief-080516MEX_Border.pdf (04. 09. 2017.).

Boggs, C. (2015). Mexico's Souther Border plan: More Deportation and Widespread Human Rights Violations, https://www.wola.org, 19. ožujka, 2015., https:// www.wola.org/analysis/mexicos-southern-border-plan-more-deportations-andwidespread-human-rights-violations/ (14. 09. 2017.).

Browing, C. (2017). Security and migration: a conceptual exploration, u: P. Bourbeau (ur.). Handbook on Migration and Security. Cheltenham: Edward Elgar Publishing, 39-59.

Buzan, B., Wæver, O. i de Wilde. J. (1998). Security: A New Framework for Analysis. Boulder: Lynne Rienner Publishers.

Castillo, A. (2016). Programa Frontera Sur: Mexican Goverment's Faulty Immigration Policy, u: Council on Hemispheric Affairs, http://www.coha.org, 26. listopada, 2016., http://www.coha.org/programa-frontera-sur-the-mexican-governments-faultyimmigration-policy/ (07. 02. 2017.).

Castles, S., de Haas, H. i Miller, M. (2014). The Age of Migration: International Population Movements in the Modern World, 5th Edition. Basingstoke: Palgrave Macmillan.

Chishti, M. i Hipsman, F. (2016). Increased Central American Migration to the United States May Prove an Enduring Phenomenon, www.migrationpolicy.org, 18. veljače, 2016., http://www.migrationpolicy.org/article/increased-central-americanmigration-united-states-may-prove-enduring-phenomenon (04. 09. 2017.).

Domínquez, J. I. (2010). The changes in the International System during the 2000s, u: J. I. Domínquez i R. Fernández de Castro (ur.). Contemporaray US - Latin American Relations Cooparation or Conflict in the 21st Century?. New York - London: Routledge, $1-16$.

Donnelly, R. (2014). Transit Migration in Mexico: Domestic and International Policy Implications. Houston: Rice University's Baker Institute for Public Policy, http://www. bakerinstitute.org/research/transit-migration-mexico-domestic-and-internationalpolicy-implications/ (05. 09. 2017.). 
Haines, D. (2013). Migration, Policy, and Anthropology, International Migration, 51 (2): 77-89, doi: https://doi.org/10.1111/imig.12080

Hiskey, J., Cordova, A., Orces, D. i Malone, M. F. (2016). Understanding the Central American Refugee Crisis, Why They Are Fleeing and How US Policies are Failing to Deter Them. Washington D. C.: American Immigration Council (Special Report), https:// www.americanimmigrationcouncil.org/research/understanding-central-americanrefugee-crisis (07. 09. 2017.).

Isacson, A. Meyer, M. i Morales, G. (2014). Mexico's Other Border Security, Migration, and the Humanitarian Crisis at the Line with Central America. Washinton: Washinton Office on Latin America, https://www.wola.org/wp-content/uploads/2014/06/MexicosOther-Border-PDF.pdf (18. 08. 2017.).

Kacowicz, A. (2016). Latin America in the new world security architecture, u: D. Mares i A. Kacowicz (ur.). Routledge Handbook of Latin American Security. London - New York: Routledge, 336-347.

Kimball, A. (2007). The Transit State: A Comparative Analysis of Mexican and Moroccan Immigration Policies. La Jolla: The Center for Comparative Immigration studies, UCSD (CCIS Working paper 150), https://ccis.ucsd.edu/_files/wp150.pdf (13. 09. 2017.).

Koser, K. (2011). When is Migration a Security Issue?, https://www.brookings.edu, 31. ožujka, 2011., https://www.brookings.edu/opinions/when-is-migration-a-securityissue/ (17. 09. 2017.).

Kos-Stanišić, L. (2010). Latinska Amerika i suvremeni svijet. Zagreb: FPZG.

Kos-Stanišić, L. (2012). Marerosi - od uličnih bandi do transnacionalnih kriminalnih organizacija, Političke analize, 3 (10): 34-37.

Kos-Stanišić, L. (2013). Sigurnosne narkoprijetnje demokracijama Sjevernog trokuta, Politička misao, 50 (3): 81-101.

Kos-Stanišić, L., Čančar E. i Richardson, J. (2018). Trans-migrants in Mexico: a policy and online communications case study of the 2014 Central American Refugee Crisis in the Mexican context, Teorija in praksa, 55 (2): 462-481.

Lijphart, A. (1971). Comparative Politics and the Comparative Method, The American Political Science Review, 65 (3): 682-693.

Lindey, A. (2014). Critical perspectives on crisis and migration, https://www. opendemocracy.net, 16. svibnja, 2014., https://www.opendemocracy.net/annalindley/critical-perspectives-on-crisis-and-migration (27. 09. 2017.).

Lopez, M. N. (2015). Mexico Southern Border Strategy "Programa Frontera Sur" - Implications for Regional Cooperation and Trans-migrant Human Rights (Masters thesis in Human Rights Law and Humanitarian Action). Paris: Sciences Po, PSIA-Paris School of International Affairs.

Muggah, R. (2017). The shifting frontiers of displacement in Latin America, u: P. 
Bourbeau (ur.). Handbook on Migration and Security. Cheltenham: Edward Elgar Publishing, 395-409.

Noricumbo Robles, C. M. (2017). La seguridad fronteriza Estados Unidos - México, Foreign Affairs Latinoamerica, 4. prosinca, 2017., http://revistafal.com/la-seguridadfronteriza-estados-unidos-mexico/ (27. 09. 2017.).

Olayo-Mendez, A. (2017). La 72: an oasis along the migration routes in Mexico, Forced Migration Review, 56: 10-11.

Portillo Villeda, S. i Miklos, A. (2017). Central Americans under Trump: Uncertainty on Both Sides of the Border, LASA Forum, 48 (2): 53-59.

Ribando Seelke, C. (2013). Gangs in Central America. Washington D. C.: Congressional Research Service (CRS Reports RL34112), http://www.fas.org/sgp/crs/row/RL34112. pdf (19. 09. 2017.).

Ribando Seelke, C. (2015). Mexico's Recent Immigration Enforcement Efforts. Washington D. C.: Congressional Research Service (CRS Reports IF10215), https://www. documentcloud.org/documents/2842650-CRS-Report-US-Assistance-MexicoSouthern-Border.html (19. 09. 2017.).

Ribando Seelke, C. i Finklea, K. (2017). US - Mexican Security Cooperation: The Merida Initiative and Beyond. Washington D. C.: Congressional Research Service (CRS Reports R41349), https://fas.org/sgp/crs/row/R41349.pdf (19. 09. 2017.).

Russell, R. i Calle, F. (2007). La "periferia turbulenta" como factor de la expansion de los intereses de seguridad de Estados Unidos en America Latina, http://historiapolitica. com/datos/biblioteca/russell1.pdf (19. 09. 2017.).

Tavares, R. (2014). Security in South America: the role of the states and regional organization. Boulder: Lynne Rienner Publishers.

Thomas, G. (2011). A Typology for the Case Study in Social Science Following a Review of Definition, Discourse, and Structure. Qualitative Inquiry, 17 (6): 511-521.

United Nations Trust Fund for Human Security - UNTFHS (2009). Human Security in Theory and Practice. New York, www.un.org/humansecurity (19. 09. 2017.).

Wertheimer-Baletić, A. (1999). Stanovništvo i razvoj. Zagreb: MATE.

Wilson, C. i Valenzuela, P. (2014). Mexico's Southern Border Strategy: Programa Frontera Sur, https://www.wilsoncenter.org/sites/default/files/Mexico_Southern_ Border_Strategy.pdf (19.09. 2017.).

Wohlfeld, M. (2014). Is Migration a Security Issue?, u: O. Grech i M. Wohlfeld (ur.). Migration in the Mediterranean: Human Rights, Security and Development Perspectives. Msida: Mediterranean Academy of Diplomatic Studies, 62-77.

WOLA (2016). Child and Family Migration, From its Roots in Central America, through Mexico and the Border, to the U.S. Response. Washington D. C., https://www.wola.org/ wp-content/uploads/2016/11/Migration-Multimedia-Series-Report-Format-Digital. $\operatorname{pdf}(19.09 .2017$.$) .$ 


\title{
Illegal Migrants in Transit as a Security Threat to the Citizens of Mexico
}

\author{
Lidija Kos-Stanišić
}

\begin{abstract}
SUMMARY
This article will attempt to answer two questions; first, in what way did the Government of Mexico attempt to resolve the influx of a large number of migrants, children and family members, from the Northern Triangle countries (Guatemala, El Salvador, Honduras) who were transiting Mexico on their way to the United States in the 2014-2016 period? Second, why have migrants continued to arrive even after the adoption of the Mexican Programa Frontera Sur (PFS) of 2014, which was supposed to resolve the migration crisis and put an end to arrests and deportation? At the same time, the article will try to assess, according to Haines (2013), whether the Mexican post-2014 migration policy has been "good" (in line with the political and cultural context, achievable and effective with acceptable costs of staff and resources), or "bad" (discriminatory and incompatible with existing moral and legal norms). The thesis of the article is that under the influence of the United States, Mexico is treating migrants in transit as a security threat, rather than as members of the same cultural circle who require protection. So, instead of helping them, Mexico uses coercion to suppress them. While traditional threats are endangering the survival of the state, new threats to the state are also endangering individuals.
\end{abstract}

The article consists of an introduction, three sections and a conclusion. The first section will provide an explanation of the relationship between migration and security (traditional national security and human security). The second section analyses the pull-and-push factors of migration from the Northern Triangle countries. This is followed by Mexico's transit policy towards illegal migrants, which is discussed in the third section. Case study research was used as a methodological strategy.

The migration wave in the 2014-2016 period, consisting of many children and mothers from the Northern Triangle states transiting through Mexico on their way to the United States, was characterised as a crisis. A crisis implies the existence of a threat justifying the imposition of extraordinary measures. The issue of migrants in transit through Mexico was no novelty. Since the late 1980s, under the pressure of the United States, Mexico has been deporting migrants in transit back to their countries of origin.

As Mexico has increasingly associated with the United States, there has emerged a growing need for greater compliance with "American requirements" and for the understanding of "American fears" of illegal migrants. After 11 September 2001, the fear became almost paranoid. Mexican presidents Fox, Calderon, and Nieto brought about and implemented a restrictive migration policy in line with the US policy, according to which migrants posed a threat to national security. Although repeatedly emphasising its intention to protect the migrants in transit, Mexico 
militarised and securitised its migration policy. This was particularly apparent after the 2014 Frontera Sur programme, which applied the same methods - arrest, deportation and denial of asylum - to the vulnerable population of women and children who largely satisfied the criteria for refugee status recognition. The PFS emphasised the intent to protect migrants, to better manage border crossings and to create security and prosperity zones in the south of the country. However, after two years of the programme's implementation it can be concluded that none of the objectives above have been achieved. Indeed, migrants in transit are additionally exposed to strife, suffering, and violations of their fundamental human rights, both by criminal organisations and the forces of law and order. Therefore, their transit has become much more uncertain than it was before. At the same time, human rights are violated by the state of Mexico itself, which denies migrants the right to asylum or recognition of humanitarian visas. The border in the south of the country has not become more secure. That PFS complies with US interests is apparent from the fact that the United States is its main source of funding, since it has managed to link the combat against drugs and migrants in transit via the Merida Initiative.

The question is why have migrants continued to arrive despite everything mentioned above? It was their hope that somehow, they would reach the USA or, in the worst case, remain in Mexico. The most elementary human right, the right to life, is endangered in the countries of the Northern Triangle. In addition to personal insecurity, there are other human security threats in Guatemala, Honduras and El Salvador forcing the citizens to flee and emigrate from political, economic, environmental, and health and food insecurity.

With everything being said, it is not easy to evaluate the Mexican migration policy. From a perspective of human security, it was "bad" because it was discriminatory and incompatible with the cultural and political context, as well as with moral and legal norms. Evaluated from a national security perspective, it was "good" because it was achievable, it has yielded results with an acceptable cost of staff and resources and has achieved state interests - good relations with the United States. At the same time, it is one of the tools Mexico can use in the future if Trump should decide against Mexican interests (significant taxing of Mexican products or deporting the many Mexican citizens illegally residing in the United States).

Since Mexico, Guatemala, Honduras and El Salvador belong to the same cultural (historical, religious and linguistic circle), it was presumed that Mexico would pursue a policy that favours migrants and their protection; however, that did not happen. The authors agree with Kimball (2007: 140) that in the long run, Mexico will not be able to simultaneously advocate and implement both the pro- and anti-immigrant policy.

The problem of the migrant wave, mostly consisting of mothers and children from the Northern Triangle countries, who were in transit through Mexico during 2014-2016, was attempted to be resolved via securitisation rather than care about their security. Castles de Haas and Miller (2014: 5) state that in the case of Mexico, there is a proliferation of migration transition, since it is turning from an emigration into an immigration country. To be more specific, with Trump coming to power, Mexico is increasingly not just a transit country, but also an ultimate destination country. Trump's immigration policy regarding immigrants from Central 
America suffers from deep historical amnesia related to the role of the USA in the Central American conflict of the 1980s, which has significantly destabilised the region. Moreover, Trump denounces and demonises as dangerous criminals the families, women and children, who have fled from violence contributed to by the USA (Portillo Villeda and Miklos, 2017: 53-54). This is one of the reasons the number of arrested migrants from Central America on the southern border of the United States has significantly decreased, but the number of asylum seekers in Mexico has increased threefold. There is a hope that new Mexican president Andrés Manuel López Obrador would perceive vulnerable Northern Triangle migrants more as a threat to human rather than national security.

KEY WORDS: illegal migrants, transit, security threat, securitization, Mexico, Northern Triangle 